\title{
Pengaruh motivasi, budaya organisasi, lingkungan, dan kepuasan kerja terhadap kinerja guru SMA Kota Juang
}

\author{
Zainuddin Iba * 1, Saifuddin ${ }^{1}$, Marwan ${ }^{2}$, Win Konadi ${ }^{2}$ \\ ${ }^{1}$ Sekolah Tinggi Ilmu Ekonomi (STIE) Kebangsaan Bireuen \\ Jl. Medan-Banda Aceh, Blang Bladeh, Jeumpa, Bireuen, Aceh 24251, Indonesia. \\ ${ }^{2}$ Universitas Almuslim \\ Jl. Matang Glumpangdua, Peusangan, Bireuen, Aceh 24267, Indonesia. \\ * Corresponding Author. Email: zaiba8228@gmail.com
}

\section{ARTICLE INFO}

\section{Article History}

Received:

26 December 2020;

Revised:

28 April 2021;

Accepted:

3 May 2021

Available online:

3 May 2021

\section{Keywords}

motivasi kerja; budaya organisasi; lingkungan kerja; kepuasan kerja; kinerja guru. work motivation; organizational culture; work environment; job satisfaction; teacher performance.

\begin{abstract}
Penelitian ini bertujuan untuk mengetahui (a) pengaruh motivasi terhadap kinerja guru, (b) pengaruh budaya organisasi terhadap kinerja guru, (c) pengaruh lingkungan kerja terhadap kinerja guru, dan pengaruh kepuasan kerja terhadap kinerja guru. Penelitian ini merupakan penelitian kuantitatif dengan survei yang dilakukan terhadap 63 guru. Data dikumpulkan melalui kuesioner. Metode analisis data ialah statistik dengan pendekatan analisis jalur. Hasil penelitian menunjukkan bahwa (1) terdapat pengaruh faktor motivasi kerja guru terhadap kinerja guru, yakni sebesar 14,54\%. (2) Terdapat pengaruh faktor budaya organisasi, yakni budaya sekolah terhadap kinerja guru, sebesar 24,68 persen. (3) Terdapat pengaruh faktor lingkungan kerja terhadap kinerja guru. (4) Terdapat pengaruh faktor kepuasan kerja terhadap kinerja, yakni sebesar 13,88 persen. Hasil analisis dari nilai koefisien determinasi menjelaskan bahwa kontribusi faktor motivasi guru, budaya organisasi dan lingkungan kerja, dan kepuasan kerja terhadap kinerja guru, sebesar 70,4\%, sementara sisanya (nilai residu) dari peran variabel yang tidak diteliti sebesar $29,6 \%$. Nilai residu tersebut menunjukkan bahwa terdapat faktor-faktor lain yang dapat mempengaruhi variabel kinerja guru, seperti iklim organisasi, fasilitas kerja, pendidikan dan pelatihan.
\end{abstract}

This study aims to determine (a) the influence of motivation on teacher performance, (b) the influence of organizational culture on teacher performance, (c) the effect of work environment on teacher performance, and the effect of job satisfaction on teacher performance. This research is quantitative research with a survey conducted on 63 teachers. Data were collected through a questionnaire. The method of data analysis used is statistics with a path analysis approach. The results showed that (1) there is an influence of teacher work motivation factors on teacher performance, which is equal to $14.54 \%$. (2) There is an influence of organizational culture factors, namely school culture on teacher performance, amounting to 24.68 percent. (3) There is an influence of work environment factors on teacher performance. (4) There is an influence of job satisfaction factors on performance, which is equal to 13.88 percent. The results of the analysis of the coefficient of determination explain that the contribution of teacher motivation factors, organizational culture and work environment, and job satisfaction to teacher performance is $70.4 \%$, while the rest (residual value) from the role of the variables not studied was $29.6 \%$. The residual value indicates that there are other factors that can influence teacher performance variables, such as organizational climate, work facilities, education, and training.

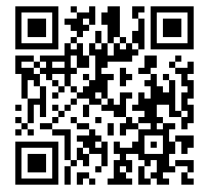

This is an open access article under the CC-BY-SA license.

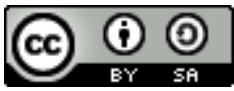

How to cite:

Iba, Z., Saifuddin, S., Marwan, M., \& Konadi, W. (2021). Pengaruh motivasi, budaya organisasi, lingkungan, dan kepuasan kerja terhadap kinerja guru SMA Kota Juang. Jurnal Akuntabilitas Manajemen Pendidikan, 9(1), 75-84. doi:https://doi.org/10.21831/jamp.v9i1.36970 


\section{PENDAHULUAN}

Manajemen sumber daya manusia merupakan salah satu sarana yang penting dalam organisasi agar para pegawai memiliki rasa kepuasan dalam bekerja. Kepuasan kerja merupakan bagian dari psikologi seseorang untuk menghasilkan perasaan terhadap perkerjaan yang dilakukan, keseimbangan antara kemampuan, keahlian dan harapan sehingga pekerja merasa puas dengan pekerjaan yang dikerjakan. Kepuasan bekerja sebenarnya bersifat subjektif membandingkan menerima, mengharapkan, dan memikirkan sesuatu yang pantas terhadap pekerjaannya. Sementara itu, setiap pegawai menentukan kepuasan dalam bekerja bersifat subjektif untuk menghasilkan pekerjaan yang memuaskan, seperti pekerjaan yang dicintai dan menyenangkan merupakan sikap emosional dari kepuasan kerja. Sikap emosional ini terbentuk dari kedisiplinan, moral kerja, dan prestasi kerja. Kepuasan kerja dapat terbentuk dari dalam maupun luar pekerjaan, dan penggabungan antara dalam dan luar pekerjaan (Indraswari, 2011). Oleh karena itu, kepuasan kerja memiliki arti yang sangat penting dari sisi pegawai maupun organisasi, serta bagi masyarakat secara umum. Meskipun demikian, kewajiban dari setiap jajaran pimpinan perusahaan adalah menciptakan keadaan yang positif yang mutlak dalam lingkungan kerja pada suatu organisasi, demikian pula dalam lingkungan sekolah.

Dalam mencapai kinerja guru, banyak faktor yang mempengaruhi, seperti motivasi kerja, budaya organisasi, lingkungan kerja, termasuk kepuasan kerja. Motivasi kerja bagi pegawai merupakan sesuatu yang harus optimal, baik dalam meningkatkan kreativitas kerjanya, dan terlebih meningkatkan kinerja, juga termasuk bagaimana visi dan misi organisasi dapat dicapai. Bagi seorang guru, diharapkan faktor internal dalam dirinya, seperti motivasi ini sangat besar perannya dalam menggerakkan dirinya untuk berprestasi, dan berafiliasi, sehingga menjadikannya sebagai faktor penting dalam mendukung kinerjanya, baik meningkatkan kompetensi kepribadian, kompetensi pedagogik, kompetensi sosial, apalagi kompetensi profesional guru. Pentingnya motivasi adalah karena motivasi merupakan hal yang menyebabkan, menyalurkan, dan mendukung perilaku manusia, agar mau bekerja giat dan antusias mencapai hasil kerja yang optimal (Hasibuan, 2005). Di samping itu, sesuai dengan hakikat motivasi sebagai proses yang mendorong dan mengarahkan perilaku, maka Gibson et al. (1996) mengemukakan bahwa motivasi merupakan konsep yang digunakan untuk menggambarkan dorongan-dorongan yang timbul pada atau di dalam diri seseorang untuk menggerakkan dan mengarahkan perilaku, sehingga dengan demikian, pada gilirannya, pegawai akan memiliki keinginan untuk bekerja dengan giat dan mencapai hasil kerja yang baik. Oleh karena itu, tidak heran jika Greenberg dan Baron (2003) mengemukakan bahwa motivasi merupakan serangkaian proses yang membangkitkan (aruose), mengarahkan (direct), dan menjaga (maintain) perilaku manusia menuju pada pencapaian tujuan.

Di samping faktor motivasi yang harus timbul pada diri seorang guru untuk berkinerja baik, faktor budaya organisasi di sekolah juga terkadang ikut berperan untuk memotivasi guru dalam meningkatkan kinerjanya. Budaya merupakan seperangkat aturan, nilai-nilai, keyakinan, dan sikap yang dapat menyesuaikan serta mendorong keterlibatan pegawai, dan dapat memperjelas tujuan dan arah strategi organisasi serta yang selalu menguraikan dan mengajarkan nilai-nilai dan keyakinan organisasi, dapat membantu organisasi mencapai pertumbuhan yang lebih tinggi atau baik. Maka, dapat diistilahkan bahwa budaya organisasi berupa nilai-nilai inilah yang menjadi pegangan bagi pegawai dalam menjalankan kewajibannya dan juga perilakunya di dalam suatu organisasi. Untuk itu, sudah selayaknya pegawai atau guru harus diajarkan cara yang benar dalam mengkaji, berpikir dan merasakan masalah yang dihadapi. Pemaksaan suatu budaya dapat menimbulkan ketidakcocokan antara pegawai dengan organisasi sehingga dapat mempengaruhi kondisi psikologis pegawai yang merasa tidak nyaman dalam bekerja sama.

Oleh karena itu, budaya organisasi mempunyai beberapa fungsi, antara lain: (1) sebagai pengikat seluruh komponen organisasi, terutama pada saat organisasi menghadapi guncangan baik dari dalam maupun dari luar akibat adanya perubahan, (2) sebagai alat untuk menyatukan beragam sifat, karakter, bakat, dan kemampuan yang ada di dalam organisasi, (3) sebagai identitas organisasi, dan yang lebih penting berfungsi (4) sebagai suntikan energi untuk mencapai kinerja yang tinggi bagi pegawai dan organisasi. Di samping itu, suatu organisasi atau sekolah harus menjaga lingkungan kerja para pegawai atau guru pada kondisi yang kondusif untuk optimal bekerja. Lingkungan kerja yang memuaskan bagi pegawainya dapat meningkatkan motivasi kerja, dan pada saat itu, akan terjadi peningkatan pula dalam kinerja pegawai. Lingkungan kerja tidak hanya terbatas dari bentuk fisik tempat bekerja saja, tetapi juga faktor-faktor lain, seperti sarana dan prasarana yang disediakan, rekan kerja, tingkat per- 
saingan, kepemimpinan, sehingga suasana kerja yang tercipta tergantung pada pola yang diciptakan pemimpinnya (Cokroaminoto, 2007). Oleh karena itu, dapat diringkas bahwa lingkungan kerja adalah segala sesuatu yang ada di sekitar tempat para pekerja bekerja, baik fisik maupun non fisik yang dapat mempengaruhi proses pekerjaan yang dikerjakan oleh pekerja atau guru di suatu sekolah tersebut.

Kinerja guru dipengaruhi oleh tingkat kepuasan guru yang dirasakannya selama dalam pelaksanaan pendidikan. Sekolah merupakan wadah tempat belajar dan pembelajaran pendidikan nasional. Kualitas kinerja guru sangat dituntut untuk dapat memberikan pelayanan pendidikan sesuai dengan standar. Dalam pencapaian tujuan tersebut, mestinya diperlukan kualitas kinerja yang diiringi dengan rasa kepuasan bagi petugas pelaksana tersebut. Ketidaknyamanan pegawai berdampak pada ketidakpuasan kerja pegawai, termasuk para guru pada suatu sekolah.

Sekolah menengah atas (SMA) di wilayah Kota Juang Bireuen adalah salah satu sekolah menengah atas di Kabupaten Bireuen, yang memiliki guru yang berstatus pegawai negeri sipil atau aparatur sipil Negara (PNS atau ASN) sebanyak 56 orang pada tahun 2018, dan meningkat pada tahun 2019 menjadi sebanyak 63 orang. Peningkatan data tersebut mengindikasikan perkembangan tingkat pendidikan menengah tak luput dari peran guru dalam melaksanakan peran dengan baik, didukung dengan tingkat pendidikan yang memenuhi standar aturan pendidikan. Kinerja guru juga terus mengalami perubahan baik, walaupun masih perlu ditingkatkan agar dapat bersaing dengan daerah lainnya.

Kepuasan kerja dapat dirasakan mulai dari pemberian motivasi, budaya organisasi yang ada dalam organisasi, dan lingkungan kerja yang termasuk pada lingkungan kerja yang sehat. Faktor itu perlu diperhatikan oleh pimpinan sekolah, yaitu kepala sekolah, yang menyelenggarakan dan melaksanakan tugas pendidikan nasional yang ada di negara kita, dan hal ini masih terjadi di SMA di wilayah Kota Juang Bireuen. Peran kepala sekolah sangat mempengaruhi para guru dan tenaga kependidikannya. Mereka bekerja penuh antusias dan keinginan yang tinggi, dengan harapan mereka bisa mendapatkan penghormatan dan kesejahteraan di dalam bekerja. Hal ini masih perlu diperhatikan lebih jauh agar kinerja para guru dan tenaga kependidikan pada SMA di wilayah Kota Juang Bireuen dapat merasakan kepuasan.

Bentuk perhatian terhadap guru masih kurang, sehingga mempengaruhi tingkat motivasi, atau keinginan guru akan menurun. Menurunnya motivasi disebabkan oleh pola budaya organisasi di dalam sekolah yang tidak baik atau kebiasaan yang buruk sehingga menciptakan pola lingkungan kerja yang tidak sehat. Berdasarkan kondisi tersebut, peneliti tertarik untuk melakukan penelitian dengan judul "Pengaruh Motivasi, Budaya Organisasi, Lingkungan Kerja, Kepuasan Kerja terhadap Kinerja Guru pada SMA di Kecamatan Kota Juang Kabupaten Bireuen" dengan tujuan untuk mengetahui (1) pengaruh motivasi kerja guru terhadap kinerja, (2) pengaruh budaya organisasi di sekolah terhadap kinerja guru, (3) pengaruh lingkungan kerja terhadap kinerja guru, dan (4) pengaruh kepuasan kerja terhadap kinerja guru.

\section{METODE}

Penelitian ini termasuk penelitian survei dengan pendekatan kuantitatif. Metode ini dipilih karena sesuai dengan tujuan dari penelitian, yaitu untuk memperoleh data yang dilakukan dengan cara mengumpulkan informasi melalui angket, sehingga dapat menjawab hal-hal yang akan diketahui tentang pengaruh antar variabel bebas dengan variabel terikat.

Dalam penelitian ini, penulis membuktikan dan dapat menjelaskan hubungan kausal antar variabel melalui pengujian hipotesis, yakni menjelaskan pengaruh variabel bebas, yakni motivasi kerja guru $\left(\mathrm{X}_{1}\right)$, budaya organisasi $\left(\mathrm{X}_{2}\right)$, lingkungan kerja $\left(\mathrm{X}_{3}\right)$ dan kepuasan kerja $\left(\mathrm{X}_{4}\right)$ terhadap variabel tidak bebas, yaitu kinerja guru (Y), dengan operasional variabel penelitian yang dinyatakan dalam Tabel 1.

Teknik analisis data dalam penelitian ini menggunakan pendekatan model analisis jalur (path analysis), dengan alasan bahwa terdapat hubungan kausal antar variabel eksogen. Untuk memperoleh persyaratan analisis, dilakukan uji klasik model regresi, yakni uji normalitas, uji multikolinieritas, dan uji Heteriskedasitas. Menurut Pedhazur (1982), yang harus dipenuhi untuk menggunakan analisis jalur ada lima, yaitu: (1) hubungan antara variabel dalam model linier, aditivitas tidak ada efek-efek interaksi dan kausal; (2) semua variabel residu (yang tidak diukur) tidak berkorelasi dengan salah satu variabel yang membangun model; (3) adanya rekursivitas, di mana semua anak panah mempunyai satu arah, tidak boleh terjadi pemutaran balik; (4) variabel yang diukur berskala interval; serta (5) variabel diukur tanpa kesalahan. 
Tabel 1. Definisi Operasionalisasi Variabel

\begin{tabular}{|c|c|c|}
\hline Variabel & Indikator & Ukuran /Skala \\
\hline Motivasi & $\begin{array}{l}\text { 1. Kebutuhan fisik, } \\
\text { 2. Kebutuhan rasa aman dan keselamatan } \\
\text { 3. Kebutuhan sosial, } \\
\text { 4. Kebutuhan akan penghargaan, } \\
\text { 5. Kebutuhan perwujudan diri, } \\
\text { Hasibuan (2014) }\end{array}$ & Likert / Ordinal \\
\hline Budaya organisasi & $\begin{array}{l}\text { 1. Peraturan } \\
\text { 2. Jarak dengan atasan } \\
\text { 3. Kepercayaan } \\
\text { 4. Profesionalisme } \\
\text { 5. Integrasi } \\
\text { Indraswari (2011) }\end{array}$ & Likert / Ordinal \\
\hline Lingkungan kerja & $\begin{array}{l}\text { 1. Suasana Kerja } \\
\text { 2. Hubungan Dengan Rekan Kerja } \\
\text { 3. Tersedianya Fasilitas Kerja } \\
\text { Nitisemito (2006) }\end{array}$ & Likert / Ordinal \\
\hline Kepuasan kerja & $\begin{array}{l}\text { 1. Kesetiaan } \\
\text { 2. Kemampuan } \\
\text { 3. Kejujuran } \\
\text { 4. Kreativitas } \\
\text { 5. Kepemimpinan } \\
\text { 6. Tingkat Gaji } \\
\text { 7. Kompensasi tidak langsung } \\
\text { 8. Lingkungan Kerja } \\
\text { Hasibuan (2012) }\end{array}$ & Likert / Ordinal \\
\hline Kinerja & $\begin{array}{l}\text { 1. Kualitas } \\
\text { 2. Kuantitas } \\
\text { 3. Keandalan } \\
\text { 4. Sikap } \\
\text { Mangkunegara (2015) }\end{array}$ & Likert / Ordinal \\
\hline
\end{tabular}

\section{HASIL DAN PEMBAHASAN}

Hasil

Data penelitian berskala ordinal. Hasil skor jawaban responden (guru) dilihat dengan skala Likert-5, sehingga untuk kepentingan analisis, dilakukan konversi data ke skala interval dengan MSI. Hasil verifikasi data terbukti memenuhi ketentuan tentang validitas dan reliabilitas alat ukur, di mana dari 63 unit data guru, rata-rata validitas item pernyataan yang mengukur variabel, dan tingkat reliabilitasnya disajikan dalam Tabel 2.

Tabel 2. Validitas dan Reliabilitas Instrumen Pengukur Variabel

\begin{tabular}{clccc}
\hline No & \multicolumn{1}{c}{ Variabel } & Jumlah Item & Rata-rata Validitas & Tk Reliabilitas \\
\hline 1 & Motivasi kerja guru & 9 & 0,488 & 0,653 \\
2 & Budaya Organisasi & 14 & 0,688 & 0,906 \\
3 & Lingkungan Kerja (Sekolah) & 6 & 0,654 & 0,753 \\
4 & Kepuasan kerja & 8 & 0,580 & 0,690 \\
5 & Kinerja guru & 10 & 0,575 & 0,759 \\
\hline
\end{tabular}

\section{Analisis Deskriptif Data Penelitian}

Analisis deskriptif menunjukkan gambaran mengenai data yang akan diteliti atau untuk menguraikan kecenderungan jawaban responden dari tiap variabel. Berdasarkan hasil kuesioner dari 63 guru SMA di wilayah Kota Juang Bireuen, diperoleh jawaban dari variabel bebas motivasi guru, budaya organisasi, lingkungan kerja, kepuasan kerja, dan variabel terikat kinerja guru, disajikan dalam Tabel 3. 
Tabel 3. Deskripsi Guru SMAN 2 Bireuen tentang Variabel yang Diukur

\begin{tabular}{lcccccc}
\hline \multirow{2}{*}{\multicolumn{1}{c}{ Variabel }} & \multicolumn{9}{c}{ Persentase Jawaban } & Skor \\
\cline { 2 - 7 } & STS & TS & KS & S & SS & Pencapaian \\
\hline Motivasi kerja guru & 0,00 & 1,59 & 13,58 & 50,79 & 34,04 & $83,46 \%$ \\
Budaya Organisasi & 0.00 & 0.91 & 5.22 & 57.60 & 36.28 & $85,85 \%$ \\
Lingkungan Kerja (Sekolah) & 0.00 & 0.00 & 14.29 & 61.64 & 24.07 & $81,96 \%$ \\
Kepuasan kerja & 0.00 & 1.39 & 6.35 & 68.65 & 23.61 & $82,89 \%$ \\
Kinerja guru & 1.11 & 1.90 & 11.75 & 50.95 & 34.29 & $83,08 \%$ \\
\hline
\end{tabular}

Berdasarkan Tabel 3, motivasi guru termasuk baik dalam mendukung kinerja guru SMA di Kota Juang Bireuen. Skor penilaian motivasi guru mencapai 83,46\%. Budaya sekolah, menurut guru di SMA di wilayah Kota Juang Bireuen, sudah baik mencapai 85,85\%, sedangkan lingkungan kerja, menurut penilaian guru, sudah cukup baik, yaitu $81,96 \%$. Kepuasan kerja guru, menurut penilaian guru, sudah baik, yaitu 82,89 \%, dan tingkat kinerja guru sudah mencapai kategori baik, yakni 83,08 \%.

\section{Uji Normalitas}

Uji normalitas adalah sebuah uji yang dilakukan dengan tujuan untuk menilai sebaran data pada sebuah kelompok data atau variabel, apakah sebaran data tersebut berdistribusi normal ataukah tidak. Uji normalitas berguna untuk menentukan data yang telah dikumpulkan berdistribusi normal atau diambil dari populasi normal. Hasil pengujian normalitas dapat dilihat pada Gambar 1. Data dikatakan berdistribusi normal, jika data menyebar disekitar garis diagonal dan mengikuti arah garis diagonal atau grafik histogramnya. Maka, kurva pada Gambar 1 membuktikan asumsi normalitas tercapai.

Scatterplot

Normal P-P Plot of Regression Standardized
Residual

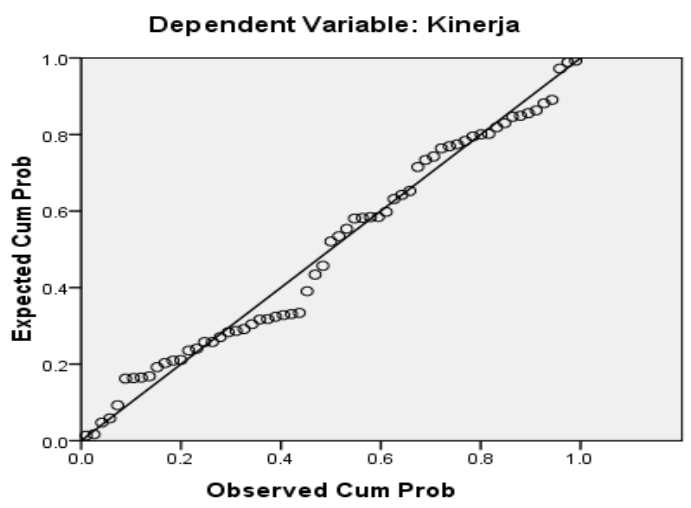

Gambar 1. Uji Normalitas Data

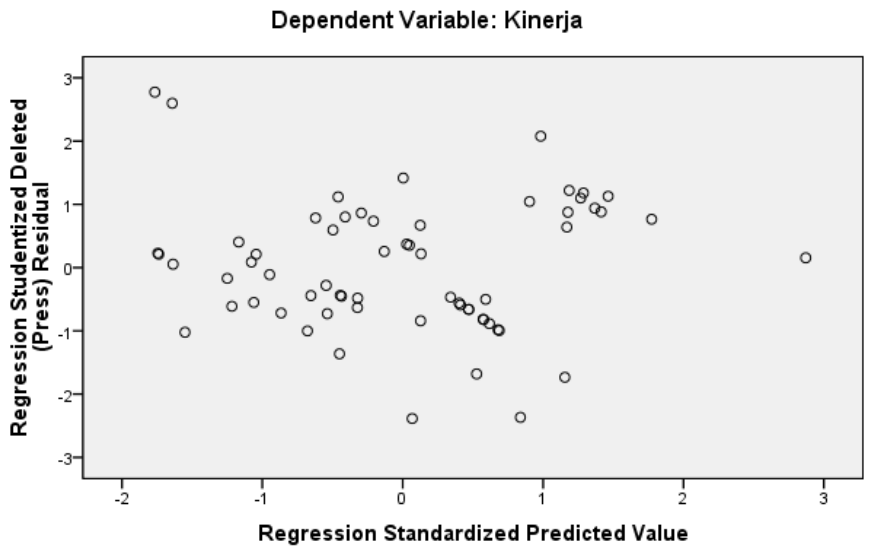

Gambar 2. Uji Heterokedastisitas

\section{Uji Heteroskedastisitas}

Uji heteroskedastisitas ialah uji yang menilai apakah ada ketidaksamaan varian dari residual untuk semua pengamatan pada model regresi linear. Uji ini adalah salah satu uji asumsi klasik yang harus dilakukan pada regresi. Dari Gambar 2, titik-titik data menyebar di atas dan di bawah atau sekitar angka 0 . Penyebaran titik-titik data tidak membentuk pola bergelombang melebar lalu menyempit dan melebar kembali, atau penyebaran data tidak berpola, sehingga tidak terjadi masalah heteroskedasitas.

\section{Uji Multikolinearitas}

Multikolinearitas adalah sebuah situasi yang menunjukkan adanya korelasi atau hubungan kuat antara dua variabel bebas atau lebih dalam sebuah model regresi berganda. Multikolinearitas tidak mengurangi kekuatan prediksi secara simultan, namun mempengaruhi nilai prediksi dari sebuah variabel 
bebas. Mendeteksi adanya multikolineritas dilihat dari nilai Tolerance dan Variance Inflating Factor (VIF). Jika nilai Tolerance < 0,1 dan VIF > 10, dapat diindikasikan adanya multikolinearitas. Hasil pengujian multikollinieritas data dalam penelitian ini menggunakan alat bantu SPSS. Hasilnya dapat dilihat pada Tabel 4, bahwa variabel bebas yang memiliki nilai VIF di bawah 10 dan mempunyai angka tolerance di atas 0 , sehingga, tidak ada multikollinieritas antar variabel bebas dalam model regresi.

Tabel 4. Hasil Uji Multikolinearitas

\begin{tabular}{ccc}
\hline & Collinearity Statistics & \\
\hline & Tolerance & VIF \\
\hline Motivasi kerja guru & 0,602 & 1,662 \\
Budaya Organisisasi & 0,516 & 1,938 \\
Lingkungan Kerja (Sekolah) & 0,449 & 2,225 \\
Kepuasan kerja & 0,546 & 1,831 \\
\hline
\end{tabular}

\section{Path Analysis}

Uji Model Secara Simultan

Metode dianalisis dengan analisis jalur yang menentukan pengaruh variabel motivasi kerja $\left(\mathrm{X}_{1}\right)$, budaya organisasi $\left(\mathrm{X}_{2}\right)$, lingkungan kerja $\left(\mathrm{X}_{3}\right)$, kepuasan kerja $\left(\mathrm{X}_{4}\right)$, terhadap kinerja guru $(\mathrm{Y})$, dengan model $Y=\rho_{1} X_{1}+\rho_{2} X_{2}+\rho_{3} X_{3}+\rho_{4} X_{4}+$ e. Adapun pembuktian hipotesis secara simultan (keseluruhan) dapat dilihat pada Tabel 5.

Tabel 5. Uji Model Analisis Secara Simultan

\begin{tabular}{cccccc}
\hline Model & Sum of Squares & df & Mean Square & F & Sig. \\
\hline Regression & 1051.333 & 4 & 262.833 & 34.504 & .000 \\
Residual & 441.819 & 58 & 7.618 & & \\
Total & 1493.152 & 62 & & & \\
\hline
\end{tabular}

a. Predictors: (Constant), kepuasan, Motivasi, Budaya, Lingkungan

b. Dependent Variable: Kinerja

Berdasarkan hasil uji $\mathrm{F}$, diperoleh nilai $\mathrm{F}_{\text {hitung }} 34,504$, dan signifikansi pada 0.000. Maka probabilitas dalam penelitian ini $<0,05 \%$ sehingga variabel motivasi kerja $\left(\mathrm{X}_{1}\right)$, budaya organisasi $\left(\mathrm{X}_{2}\right)$, lingkungan kerja $\left(\mathrm{X}_{3}\right)$, kepuasan kerja $\left(\mathrm{X}_{4}\right)$, secara simultan berpengaruh terhadap kinerja guru $(\mathrm{Y})$.

Penentuan Koefisien Korelasi (r) dan Koefisien Jalur (P)

Selanjutnya, dilakukan pengujian: hipotesis yang diajukan diuji untuk menjawab masalah penelitian yang dirumuskan, dilanjutkan dengan pengujian model yang dihipotesiskan, menentukan pengaruh langsung dan tidak langsung, dan pembahasan hasil penelitian. Pertama, dilakukan taksiran nilai kausalitas antar variabel Eksogenus $\left(\mathrm{X}_{1}, \mathrm{X}_{2}, \mathrm{X}_{3}, \mathrm{X}_{4}\right)$ (Tabel 6). Terbukti terdapat hubungan kausalitas antar variabel independen (Eksogenus). Setelah itu, nilai koefisien jalur antar variabel eksogen $\left(\mathrm{X}_{1}, \mathrm{X}_{2}\right.$, $\mathrm{X}_{3}, \mathrm{X}_{4}$ ) terhadap variabel endogen (Y) ditaksir, sebagaimana disajikan dalam Tabel 7.

Tabel 6. Hubungan Kausal Antar Variabel Bebas (Eksogenus)

\begin{tabular}{llcccc}
\hline & & Motivasi & Budaya & Lingkungan & Kepuasan \\
\hline Motivasi & Pearson Correlation & 1 & $.463^{* *}$ & $.617^{* *}$ & $.357^{* * *}$ \\
& Sig. (2-tailed) & & .000 & .000 & .004 \\
Budaya & Pearson Correlation & & 1 & $.592^{* *}$ & $.622^{* *}$ \\
& Sig. (2-tailed) & & & .000 & .000 \\
\multirow{2}{*}{ Lingkungan } & Pearson Correlation & & & 1 & $.573^{* *}$ \\
& Sig. (2-tailed) & & & .000 \\
\hline
\end{tabular}

**. Correlation is significant at the 0.01 level (2-tailed). 
Tabel 7. Taksiran Koefisien Jalur

\begin{tabular}{llccc}
\hline \multirow{2}{*}{ Model } & $\begin{array}{c}\text { Standardized Coefficients } \\
\text { Beta }=\rho\end{array}$ & t & Sig. \\
\hline Variabel & Motivasi kerja guru & 0.235 & 2.552 & 0.013 \\
& Budaya Organisisasi & 0.340 & 3.418 & 0.001 \\
& Lingkungan Kerja & 0.243 & 2.282 & 0.026 \\
& Kepuasan kerja & 0.214 & 2.216 & 0.031 \\
\hline
\end{tabular}

Atas dasar nilai statistik t, Tabel 7 menunjukkan bahwa keempat koefisien jalur dinyatakan signifikansi pada taraf uji 5\%. Berdasarkan hal tersebut, yakni hubungan antar variabel eksogen, dan nilai koefisien jalur $(\rho)$, maka dari model kausal yang dibentuk secara teoritis, diperoleh diagram jalur seperti Gambar 3, di mana $X_{1}=$ motivasi guru, $X_{2}=$ budaya organisasi, $X_{3}=$ lingkungan kerja, $\mathrm{X}_{4}=\mathrm{Ke}-$ puasan kerja, $\mathrm{Y}=$ Kinerja guru, $\mathrm{r}_{\mathrm{xi}, \mathrm{xj}}=$ Hubungan kausal antar variabel eksogen diukur dengan koefisien korelasi, $\rho_{\mathrm{yxi}}=$ Nilai koefisien jalur ( path) yang menyatakan pengaruh langsung antar variabel eksogen terhadap variabel endogen.

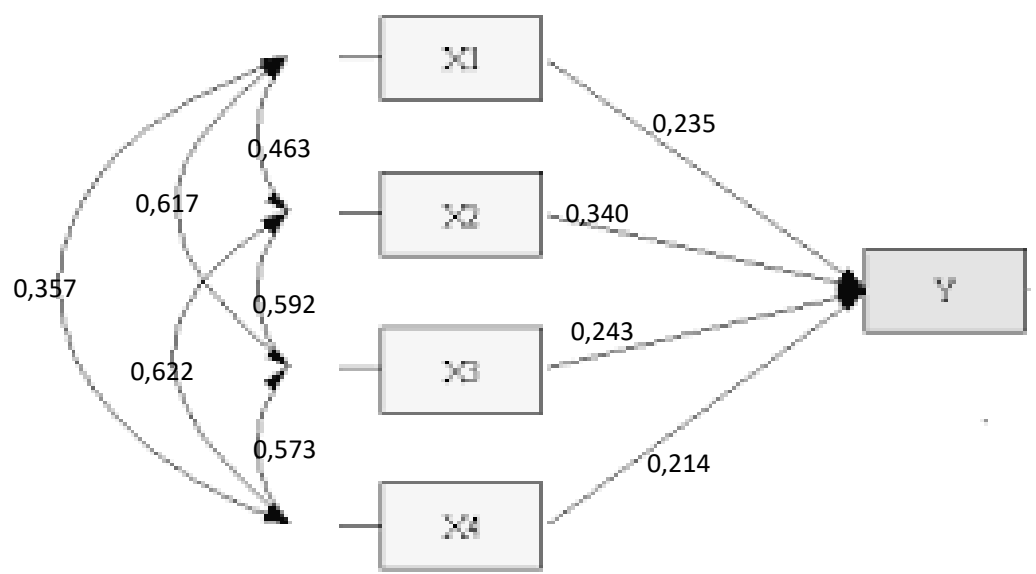

Gambar 3. Diagram Jalur Penelitian

Korelasi dan Determinasi

Untuk meyakinkan adanya keterkaitan antar variabel yang diteliti, juga didukung dari nilai statistik koefisien korelasi $(\mathrm{R})$ dan koefisien determinasi $\left(\mathrm{R}^{2}\right)$, maka, analisis koefisien korelasi dan determinasi variabel bebas $(\mathrm{X})$ dengan variabel terikat $(\mathrm{Y})$ dapat dilihat dari Tabel 8. Dari hasil analisis koefisien korelasi antara motivasi guru, budaya organisasi dan lingkungan kerja, dan kepuasan kerja terhadap kinerja guru SMA di Kota Juang Kabupaten Bireuen, diperoleh $R$ sebesar 0,839 yang menjelaskan bahwa hubungan antara motivasi guru, budaya organisasi dan lingkungan kerja, dan kepuasan kerja terhadap kinerja guru SMA se-Kecamatan Kota Juang Kabupaten Bireuen, memiliki keeratan yang cukup tinggi, dan berhubungan secara linier, dengan derajat hubungannya sebesar 0,839 .

Tabel 8. Koeisien Korelasi Simultan

\begin{tabular}{cccc}
\hline $\mathbf{R}$ & R Square & Adjusted R Square & Std. Error of Estimate \\
\hline 0.839 & 0.704 & 0.684 & 2.759993 \\
\hline
\end{tabular}

\section{Pembahasan}

Besarnya pengaruh tidak langsung motivasi kerja guru $\left(\mathrm{X}_{1}\right)$ terhadap kinerja guru $(\mathrm{Y})$ karena adanya hubungan kausal motivasi kerja dengan $\mathrm{X}_{2}$ (budaya organisasi), $\mathrm{X}_{3}$ (lingkungan kerja), dan $\mathrm{X}_{4}$ (kepuasan kerja) dinyatakan dengan besaran koefisien jalur, dan koefisien korelasi dari hubungan antar variabel dimaksud, yaitu: pengaruh motivasi $\left(\mathrm{X}_{1}\right)$ dengan budaya organisasi $\left(\mathrm{X}_{2}\right)$ terhadap kinerja guru $(\mathrm{Y})$, adalah 3,70\%. Selain itu, pengaruh motivasi $\left(\mathrm{X}_{1}\right)$ dengan lingkungan kerja $\left(\mathrm{X}_{3}\right)$ terhadap kinerja guru $(\mathrm{Y})$, adalah $3,52 \%$. Pengaruh motivasi $\left(\mathrm{X}_{1}\right)$ dengan kepuasan kerja $\left(\mathrm{X}_{4}\right)$ terhadap kinerja guru 
(Y), adalah 1,79\%. Berdasarkan pengaruh langsung dan tidak langsung, maka dapat dihitung besarnya pengaruh total motivasi $\left(\mathrm{X}_{1}\right)$ terhadap kinerja guru $(\mathrm{Y})$, yakni: 14,54\%. Dari hasil uji hipotesis, dapat disimpulkan bahwa terdapat pengaruh positif motivasi kerja terhadap kinerja guru SMA di Kecamatan Kota Juang Kabupaten Bireuen. Selanjutnya, pengaruh total menunjukkan persentase lebih tinggi daripada pengaruh langsung. Besaran koefisien motivasi juga berpengaruh tidak langsung dalam budaya organisasi terhadap kinerja guru, lebih tinggi persentase dibandingkan lingkungan kerja dan kepuasan kerja guru SMA di Kecamatan Kota Juang Kabupaten Bireuen. Hasil penelitian ini mendukung penelitian Imroatun dan Sukirman (2016) bahwa ada pengaruh positif secara parsial antara motivasi kerja terhadap kinerja guru SMA Negeri se-Kabupaten Wonosobo. Motivasi kerja sangat efektif untuk memenuhi dan meningkatkan kinerja guru, di mana faktor-faktor motivasi kerja tersebut diukur. Hal ini biasa diartikan bahwa indikator-indikator dalam motivasi kerja mempunyai pengaruh terhadap kinerja. Adapun indikator yang berpengaruh, antara lain, kondisi lingkungan kerja, karena dalam tanggapan responden menunjukkan persentase yang sangat tinggi. Motivasi kerja merupakan bagian yang tidak dapat dipisahkan dari kinerja, baik bagi individu maupun kelompok, dan merupakan faktor dominan yang mempengaruhi kinerja (Tetuko, 2012). Adanya hubungan kausal antar variabel motivasi dengan variabel eksogen lainnya terhadap variabel tujuan yakni kinerja guru, maka secara statistik, analisis jalur dihitung, baik pengaruh langsung (direct) dan pengaruh tidak langsung (undirect). Besarnya pengaruh langsung motivasi kerja guru $\left(\mathrm{X}_{1}\right)$ terhadap kinerja guru $(\mathrm{Y})$ dinyatakan dengan besaran koefisien jalur $\left(\rho_{\mathrm{yx} 1}=0,235\right)$, sehingga besarnya pengaruh langsung ini adalah 5,52\%.

Pengaruh langsung budaya organisasi $\left(\mathrm{X}_{2}\right)$ terhadap kinerja guru $(\mathrm{Y})$, dinyatakan dengan besaran koefisien jalur $\left(\rho_{\mathrm{yx} 2}=0,340\right)$, sehingga besarnya pengaruh langsung ini adalah $11,56 \%$. Besarnya pengaruh tidak langsung budaya organisasi $\left(\mathrm{X}_{2}\right)$ terhadap kinerja guru $(\mathrm{Y})$, karena adanya hubungan kausal budaya organisasi dengan $\mathrm{X}_{1}$ (motivasi), $\mathrm{X}_{3}$ (lingkungan kerja), dan $\mathrm{X}_{4}$ (kepuasan kerja) dinyatakan dengan besaran koefisien jalur, dan koefisien korelasi dari hubungan antar variabel dimaksud, yaitu: pengaruh budaya organisasi $\left(\mathrm{X}_{2}\right)$ dengan motivasi $\left(\mathrm{X}_{1}\right)$ terhadap kinerja guru $(\mathrm{Y})$, adalah $3,70 \%$, pengaruh budaya organisasi $\left(\mathrm{X}_{2}\right)$ dengan lingkungan kerja $\left(\mathrm{X}_{3}\right)$ terhadap kinerja $(\mathrm{Y})$, adalah $4,89 \%$, dan pengaruh budaya organisasi $\left(\mathrm{X}_{2}\right)$ dengan kepuasan kerja $\left(\mathrm{X}_{4}\right)$ terhadap kinerja guru $(\mathrm{Y})$, adalah $4,53 \%$. Sementara itu, pengaruh total budaya organisasi $\left(\mathrm{X}_{2}\right)$ terhadap kinerja guru $(\mathrm{Y})$ yakni $18,46 \%$. Dari hasil uji hipotesis, dapat disimpulkan bahwa terdapat pengaruh positif budaya organisasi terhadap kinerja guru SMA di Kecamatan Kota Juang Kabupaten Bireuen. Selanjutnya, pengaruh total menunjukkan persentase lebih tinggi daripada pengaruh langsung. Besaran koefisien budaya organisasi juga berpengaruh tidak langsung dengan lingkungan kerja terhadap kinerja guru; lebih tinggi persentase dibandingkan dengan kepuasan kerja dan motivasi kerja guru SMA di Kecamatan Kota Juang Kabupaten Bireuen. Budaya kerja merupakan faktor yang memiliki pengaruh positif (signifikan) terhadap kinerja tenaga pengajar di Yayasan Pendidikan Luar Biasa (Arianto, 2013). Hasil penelitian ini juga didukung oleh penelitian dari Julianti (2010) yang menyatakan bahwa budaya kerja berpengaruh positif dan signifikan terhadap kinerja karyawan.

Pengaruh langsung lingkungan kerja $\left(\mathrm{X}_{3}\right)$ terhadap kinerja guru $(\mathrm{Y})$ dinyatakan dengan besaran koefisien jalur ( $\rho_{\mathrm{yx} 3}=0,243$ ), sehingga besarnya pengaruh langsung ini adalah $5,91 \%$. Besarnya pengaruh tak langsung lingkungan kerja $\left(\mathrm{X}_{3}\right)$ terhadap kinerja guru $(\mathrm{Y})$, karena adanya hubungan kausal lingkungan kerja $\left(\mathrm{X}_{3}\right)$ dengan motivasi $(\mathrm{X} 1)$, budaya organisasi $\left(\mathrm{X}_{2}\right)$ dan kepuasan kerja $\left(\mathrm{X}_{4}\right)$, dinyatakan dengan besaran koefisien jalur, dan koefisien korelasi dari hubungan antar variabel dimaksud, yaitu sebagai berikut: pengaruh lingkungan kerja $\left(\mathrm{X}_{3}\right)$ dengan motivasi guru $\left(\mathrm{X}_{1}\right)$ terhadap kinerja guru (Y) adalah 3,52\%, dan pengaruh lingkungan kerja $\left(\mathrm{X}_{3}\right)$ dengan budaya organisasi $\left(\mathrm{X}_{2}\right)$ terhadap kinerja guru $(\mathrm{Y})$ adalah 4,90\%, serta pengaruh lingkungan kerja $\left(\mathrm{X}_{3}\right)$ dengan kepuasan kerja $\left(\mathrm{X}_{4}\right)$ terhadap kinerja guru $(\mathrm{Y})$ adalah $2,98 \%$. Sementara itu, pengaruh total lingkungan kerja $\left(\mathrm{X}_{3}\right)$ terhadap kinerja guru (Y), yakni 13,81\%. Dari hasil uji hipotesis, dapat disimpulkan bahwa terdapat pengaruh positif lingkungan kerja terhadap kinerja guru SMA di Kecamatan Kota Juang Kabupaten Bireuen. Selanjutnya, pengaruh total menunjukkan persentase lebih tinggi daripada pengaruh langsung. Besaran koefisien lingkungan kerja juga berpengaruh tidak langsung dengan budaya organisasi terhadap kinerja guru; lebih tinggi persentase dibandingkan motivasi kerja dan kepuasan kerja guru SMA di Kecamatan Kota Juang Kabupaten Bireuen. Hasil penelitian ini sesuai dengan penelitian Syafrina dan Manik (2018) bahwa lingkungan kerja berpengaruh positif dan signifikan terhadap kinerja guru, serta memiliki hubungan yang sangat erat terhadap kinerja guru. Artinya, semakin baik lingkungan kerja, maka kinerja guru akan meningkat. Hasil penelitian ini tidak sesuai dengan hasil penelitian yang dilakukan oleh Sari 
(2013) yang menunjukkan bahwa lingkungan kerja berpengaruh negatif terhadap kinerja. Hal ini dapat terjadi karena, pada dasarnya, semua kenyamanan fisik dan non fisik, apabila semakin dipermudah, akan membuat guru menjadi kurang tertantang dalam bekerja.

Pengaruh langsung kepuasan kerja $\left(\mathrm{X}_{4}\right)$ terhadap kinerja guru $(\mathrm{Y})$ dinyatakan dengan besaran koefisien jalur ( $\rho_{\mathrm{yx} 4}=0,214$ ), sehingga besarnya pengaruh langsung ini adalah $4,58 \%$. Besarnya pengaruh tidak langsung kepuasan kerja $\left(\mathrm{X}_{4}\right)$ terhadap kinerja guru $(\mathrm{Y})$, karena adanya hubungan kausal kepuasan kerja $\left(\mathrm{X}_{4}\right)$ dengan motivasi $(\mathrm{X} 1)$, budaya organisasi $\left(\mathrm{X}_{2}\right)$ dan lingkungan kerja $\left(\mathrm{X}_{3}\right)$, dinyatakan dengan besaran koefisien jalur. Koefisien korelasi dari hubungan antar variabel dimaksud, yaitu pengaruh kepuasan kerja $\left(\mathrm{X}_{4}\right)$ dengan motivasi guru $\left(\mathrm{X}_{1}\right)$ terhadap kinerja guru $(\mathrm{Y})$ adalah $1,79 \%$, pengaruh kepuasan kerja $\left(\mathrm{X}_{4}\right)$ dengan budaya Organisasi $\left(\mathrm{X}_{2}\right)$ terhadap kinerja guru $(\mathrm{Y})$ adalah $4,53 \%$, serta pengaruh kepuasan kerja $\left(\mathrm{X}_{4}\right)$ dengan lingkungan kerja $\left(\mathrm{X}_{3}\right)$ terhadap kinerja guru $(\mathrm{Y})$ adalah $2,98 \%$. Sementara itu, pengaruh total kepuasan kerja $\left(\mathrm{X}_{4}\right)$ terhadap kinerja guru $(\mathrm{Y})$ yakni $13,88 \%$. Dari hasil uji hipotesis, dapat disimpulkan bahwa terdapat pengaruh positif kepuasan kerja terhadap kinerja guru SMA di Kecamatan Kota Juang Kabupaten Bireuen. Selanjutnya, pengaruh total menunjukkan persentase lebih tinggi daripada pengaruh langsung. Besaran koefisien kepuasan kerja juga berpengaruh tidak langsung dengan budaya organisasi terhadap kinerja guru lebih tinggi persentase dibandingkan motivasi dan lingkungan kerja guru SMA di wilayah Kabupaten Bireuen. Dengan demikian, dapat disimpulkan bahwa kepuasan kerja mempunyai pengaruh positif dan signifikan terhadap kinerja guru SMA di Kecamatan Kota Juang Kabupaten Bireuen. Hasil penelitian ini didukung oleh penelitian Laschinger et al. (2004) yang menemukan bahwa kepuasan kerja berpengaruh signifikan positif terhadap kinerja pegawai. Selain itu, Robbins (2002) menyatakan bahwa "kinerja adalah sebagai suatu fungsi dan interaksi antara kemampuan dan inovasi”.

Nilai koefisien determinasi sebesar 0,704 menjelaskan bahwa kontribusi faktor motivasi guru, budaya organisasi dan lingkungan kerja, dan kepuasan kerja terhadap kinerja guru SMA se-Kecamatan Kota Juang Kabupaten Bireuen, sebesar 70,4\%, sementara sisanya (nilai residu) dari peran variabel yang tidak diteliti sebesar $29,6 \%$. Nilai residu tersebut menunjukkan bahwa terdapat faktor-faktor lain yang dapat mempengaruhi variabel kinerja guru, seperti iklim organisasi, fasilitas kerja, pendidikan dan pelatihan, dan lain-lain. Dengan demikian, motivasi guru, budaya organisasi dan lingkungan kerja, dan kepuasan kerja memiliki hubungan yang kuat dalam mempengaruhi kinerja guru SMA se-Kecamatan Kota Juang Kabupaten Bireuen.

\section{SIMPULAN}

Berdasarkan pembahasan hasil penelitian, maka dapat ditarik simpulan bahwa hasil analisis menunjukkan adanya pengaruh faktor motivasi kerja guru terhadap kinerja guru SMA di Kecamatan Kota Juang Kabupaten Bireuen, yakni sebesar 14,54\%. Hasil analisis data juga membuktikan adanya pengaruh faktor Budaya organisasi, yakni budaya sekolah terhadap kinerja guru SMA di Kecamatan Kota Juang Kabupaten Bireuen, yakni sebesar 24,68\%. Hasil analisis selanjutnya menunjukkan adanya pengaruh faktor lingkungan kerja terhadap kinerja guru SMA di Kecamatan Kota Juang Kabupaten Bireuen, yakni sebesar $17,31 \%$, serta terdapat pengaruh faktor kepuasan kerja terhadap kinerja guru SMA di Kecamatan Kota Juang Kabupaten Bireuen, yakni sebesar 13,88\%. Hasil analisis deskriptif menunjukkan bahwa (1) variabel motivasi guru termasuk baik dalam mendukung kinerja guru. Skor penilaian motivasi guru mencapai $83,46 \%$. (2) Variabel budaya sekolah, menurut persepsi guru di SMA di Kecamatan Kota Juang Kabupaten Bireuen, sudah baik, mencapai 85,85\%. (3) Variabel lingkungan kerja, menurut penilaian guru, sudah cukup baik, mencapai 81,96\%. (4) Variabel kepuasan kerja guru, menurut penilaian guru, sudah baik, mencapai 82,89\%, dan (5) tingkat kinerja guru sudah mencapai kategori baik, yakni $83,08 \%$. Hasil analisis dari nilai koefisien determinasi menjelaskan bahwa kontribusi faktor motivasi guru, budaya organisasi dan lingkungan kerja, dan kepuasan kerja terhadap kinerja guru SMA di Kecamatan Kota Juang Kabupaten Bireuen, sebesar 70,4\%, sementara sisanya (nilai residu) dari peran variabel yang tidak diteliti sebesar $29,6 \%$. Nilai residu tersebut menunjukkan bahwa terdapat faktor-faktor lain yang dapat mempengaruhi variabel kinerja guru, seperti iklim organisasi, fasilitas kerja, pendidikan dan pelatihan, dan lain-lain. Dengan demikian, motivasi guru, budaya organisasi dan lingkungan kerja, dan kepuasan kerja memiliki hubungan yang kuat dalam mempengaruhi kinerja guru SMA di Kecamatan Kota Juang Kabupaten Bireuen. 


\section{DAFTAR PUSTAKA}

Arianto, D. A. N. (2013). Pengaruh kedisiplinan, lingkungan kerja dan budaya kerja terhadap kinerja tenaga pengajar. Jurnal Economia, 9(2), 191-200. Retrieved from https://journal.uny.ac.id/index.php/economia/article/view/1809

Cokroaminoto, C. (2007). Membangun kinerja melalui motivasi kerja karyawan. PT Gramedia Pustaka Utama.

Gibson, J. L., Ivancevich, J. M., \& Donelly, J. H. (1996). Organisasi dan manajemen: Perilaku, struktur, proses (D. Wachid, trans.) (4 $4^{\text {th }} \mathrm{ed}$.). Erlangga.

Greenberg, J., \& Baron R. A. (2003). Behavior in organizations: Understanding and managing the human side of work ( ${ }^{\text {th }}$ ed.). Prentice-Hall.

Hasibuan, M. S. P. (2005). Organisasi dan motivasi. Bumi Aksara.

Hasibuan, M. S. P. (2012). Manajemen sumber daya manusia. Bumi Aksara.

Hasibuan, M. S. P. (2014). Manajemen sumber daya manusia (revised ed.). Bumi Aksara.

Imroatun, S., \& Sukirman, S. (2016). Pengaruh lingkungan kerja, kompensasi kerja, dan motivasi kerja terhadap kinerja guru Ekonomi/Akuntansi di SMA Negeri Se-Kabupaten Wonosobo. Economic Education Analysis Journal, 5(1), 181-194. Retrieved from https://journal.unnes.ac.id/sju/index.php/eeaj/article/view/9995

Indraswari, M. (2011). Pengaruh budaya organisasi dan motivasi terhadap kepuasan kerja dalam mempengaruhi kinerja karyawan kantor unit PT Telkom Regional IV Semarang. Undergraduate thesis, Universitas Diponegoro, Semarang.

Julianti, L. M. (2010). Pengaruh budaya kerja terhadap kinerja karyawan pada Pabrik Kelapa Sawit (PKS) Rambutan PTPN III (Persero). Undergraduate thesis, Universitas Sumatera Utara, Medan.

Laschinger, H. K. S., Finegan J. E., Shamian J., \& Wilk, P. (2004). A longitudinal analysis of the impact of workplace empowerment on work satisfaction. Journal of Organizational Behavior, 25(4), 527-545. https://doi.org/10.1002/job.256

Mangkunegara, A. A. A. P. (2015). Manajemen sumber daya manusia. PT Remaja Rosdakarya.

Nitisemito, A. S. (2006). Manajemen personalia (revised ed.). Ghalia Indonesia.

Pedhazur, E. J. (1982). Multiple regression in behavioral research. Holt Rinehart and Winston.

Robbins, S. P. (2002). Prinsip-prinsip perilaku organisasi (5 ${ }^{\text {th }}$ ed.) (H. Halida \& D. Sartika, trans.). Erlangga.

Sari, F. M. (2013). Pengaruh kompetensi dan lingkungan kerja terhadap kepuasan kerja dan kinerja guru di SD negeri Kecamatan Gondang Mojokerto. DiE: Jurnal Ilmu Ekonomi \& Manajemen, 9(2), 137-153. Retrieved from http://jurnal.untag-sby.ac.id/index.php/die/article/view/213

Syafrina, N., \& Manik, S. (2018). Pengaruh lingkungan kerja terhadap kinerja karyawan pada PT. Bank Syariah Mandiri. Al-Masraf: Jurnal Lembaga Keuangan dan Perbankan, 3(2), 181-191. Retrieved from https://journal.febi.uinib.ac.id/index.php/almasraf/article/view/200

Tetuko, B. (2012). Pengaruh motivasi kerja, budaya organisasi, kepemimpinan kepala sekolah terhadap kepuasan kerja dan kinerja guru SMA swasta di Kabupaten Grobogan. Educational Management, 1(2), 129-134. Retrieved from https://journal.unnes.ac.id/sju/index.php/eduman/article/view/818 